\title{
Wild Horses and other Endangered Wildlife in Mongolia
}

\author{
D. Tsevegmid and A. Dashdorj \\ Translated by the Hon. I. Montagu
}

Until the middle of the present century Mongolia was little affected by man, in the sense of interference with and distortion of the natural environment. In 1918 the population of this 600,000 -square-mile country was only 640,000 , with 9.6 million domestic animals. (The comparable figures today are $1,300,000$ and 23.4 million). Thanks to this lack of interference and the protective measures of the Mongolian People's Republic, Mongolia still has some of the rarest of the world's mammals, notably wild horse and camel, Gobi bear and Asian wild ass. The most threatened of them is the Przewalski horse, which some scientists think is extinct. But the two authors believe that it survives in small numbers. They urge the need for iarge reserved areas where livestock, which compete for the horses' grazing and water, can be eliminated.

The natural environment in Mongolia is exceptional: to the north it is affected by the moist atmosphere of the Siberian taiga; on the western border rises the mountain massif of the Altai; from the east extend plains and steppes; and the northern wing of the Central Asian desert projects into the south. The combination of moisture with aridity over an area of 600,000 square miles, and a chain of mountains rising to over $13,000 \mathrm{ft}$, results in a unique pattern of climate, and animal and plant life.

Our fauna is currently listed as including 132 species of mammals, 371 birds, niore than 20 reptiles, 62 fish and 30 molluscs, more than 80 crustaceans, over 2500 insects including about 100 caddis-flies, about 20 leeches, and more than 220 avian and mammalian parasites. Certain of these groups-such as fish, crustacea, molluscs, leeches, helminths, dragonflies, caddis-flies and insects harmful to agriculture-have been made the object of special study by our keen younger zoologists during the last twenty or thirty years. Young zoologists in the Mongolian People's Republic (MPR) are carrying out active zoological research in the fields of mammalogy, ornithology, ichthyology, hydrobiology, entomology, parasitology and helminthology.

Until about the middle of the present century, and in contrast to other countries whose resources are more developed, the animal and plant world of Mongolia, and especially its soil, air and water, have been only slightly affected by man in the sense of interference with, and distortion of, the organic environment. It is precisely thanks to this circumstance that some of the rarest animals in the world have been preserved in our country-the takh, the wild horse Equus przewalskii, the havtagai, the wild camel Camelus bactrianus ferus, 


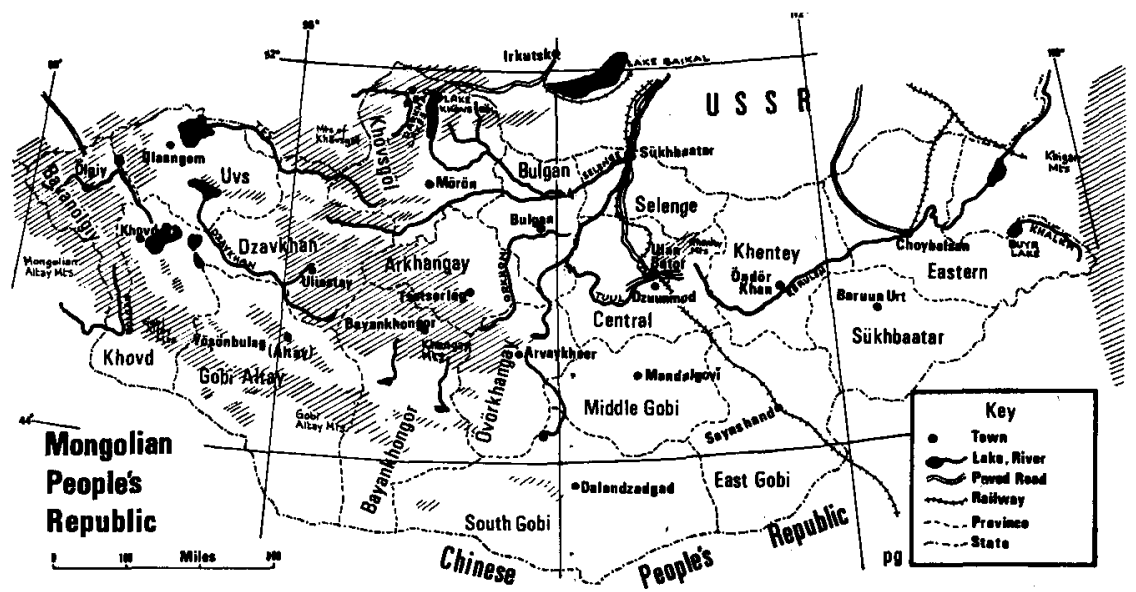

the mazaalai, the Gobi bear Ursus pruinosus, the khulan (or kulan), the Asian wild ass, E. hemionus, and the bekhen, the saiga antelope, Saiga tatarica; together these comprise 19.4 per cent of our protected animals.

Their occurrence in the south-eastern and south-western parts of Mongolia has been recorded in literature since the 18th century, some of them since the 13th century. From these contemporary accounts by travellers and scientists it is clear that their distribution was markedly wider in the past than it is today, which testifies to their present reduction in numbers. The landscape and climate of the country have changed little over the past half-century, but the pressures of human activity have greatly increased. In 1918 the 600,000 or so square miles of territory in Mongolia held some 640,000 human beings and about $9,600,000$ head of livestock; now the population is $1,300,000$ and the livestock to $23,400,000$.

The last two decades have sharply reduced the number and curtailed the area of distribution of such economically valuable animals as the tarbagan, the marmot Marmota sibirica, the dzeren Gazella gutturosa and the djeiran G. subgutturosa. However, a number of new localities have been recorded for some animals including the red-cheeked suslik (in the Dzungarian deserts, by $\mathrm{S}$. Dulamtseren, 1969); and the fauna list has been supplemented by, for example, the tamarisk gerbil and the common jerboa*.

From its earliest years the Republic has sought to protect the rare endemic animals. By a decree of 1926 the Presidium of the Great Hural of the MPR forbade the hunting of the Przewalski horse and the kulan, and further laws promulgated in 1930 and subsequent years protected many other species, including the wild camel and the

* In litt. (1973) Prof. Dashdorj has further elucidated some of these identifications: the red-cheeked ruslik Citellus erythrogenus in the river valleys of the Bulgan, Bodang, Ueng, Bit and Barlag; the tamarisk gerbil Meriones tamariscinus-river valleys of Bulgan and Bodang 1969; jerboas-the small Allactaga elater, river Bodong 1964, and the thick-tailed three-toed Scirtopoda letum, river Bolag 1969. He adds also the root-vole Microtus oeconomus - river Barlag and the Barkh hills; and the forest dormouse Dyromys nitedula in the wooded areas of the Bulgan rivervalley, June 1973. Of the marmot in Mongolia he says that two forms are recognised: Marmota bobac baibacina in the mountains of the Mongolian Altai and M. G. sibirica in Langai, Hentai, Saun, and Eastern Mongolia. M.b. caliginosus Bannikov \& Scalon 1949 they regard as a doubtful subspecies. (Translator's note). 
Gobi bear. Watch has been kept over the habitat of the kulan, wild camel and saiga and their increase in numbers, and every sighting of the Gobi bear and the Przewalski horse recorded. However, the frequent seasonal migration of herdsmen of the southern region of the Gobi-Altai aimak and their livestock into the areas where freshwater sources are to be found is driving both the horse and the bear from their age-old habitats. As a result their status has become insecure, and the need has arisen for setting aside a sufficiently large series of reserves in the south-west corner of the country.

The MPR Academy of Sciences and the State University in Ulan Bator are currently conducting research and studies on the Przewalski horse, the wild camel, the Gobi bear and other endemic or valuable introduced species.

\section{Przewalski Horse}

The Przewalski horse, the takh, perhaps the rarest of all hoofed animals in the wild, still exists in the wild state in the territory of the MPR. Twenty or thirty years ago it was seen fairly often, but of recent times encounters with either local nomadic herdsmen or zoologists have become rare. This decline may be due to the exceedingly heavy onsets of dzud (hard frost) in 1948 and 1956. Several scientists (V. G. Heptner 1961, A. G. Bannikov 1966, I. Akimushkin 1967) are even inclined to think that these animals no longer exist in the wild. But systematic investigations carried out over the last few years by Mongolian scientists (reported in D. Tsevegmid 1955, 1958; Erendendagva 1962; A. Bold 1964; I. Montagu 1964, 1965; O. Shagdarsuren 1967; N. Dovchin 1966, 1967, 1968) show clearly that the Przewalski horse still occupies a fairly large territory between the mountain chains Takhiin Shar nuruu and Baitag-bogd. The Mongolian zoologists cited above observed takh in the following localities: Tsagaan Shalyn hooloy, Shalyn us, Nuuts usny-ara, Haruul us, Honin us, Toodghiin us, Takhiin us, Avantny us, all localities in the desert rift running from the eastern end of the Baitag-bogd chain to the northern slopes of the

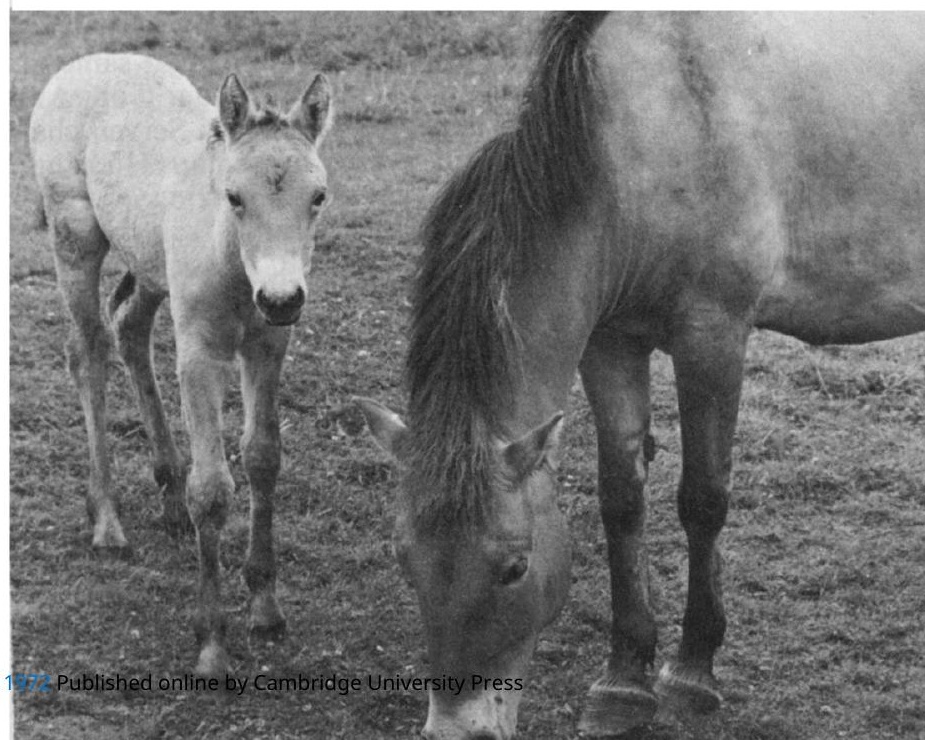


Takhiin Shar nuruu, about 200 miles long and about 125 miles wide.

The Przewalski horse is fairly often met with in the spring and summer months, but is rarely seen in the rest of the year. This is to be explained by the rival contenders for the late summer grazing and fresh water in the shape of domestic livestock, and also by the changing seasons. Interrogation of the herdsmen and personal observations have shown that the main takh herds migrate for pasture to the valleys intersecting the hills on the southern slopes of the Takhiin Shar nuruu (the Chinese side) in autumn and winter. Only in spring and early summer do they stay on the intricate northern slopes of the Takhiin Shar (the Mongolian side) where they are most frequently seen.

We accept the comparatively few observations given below, although we have reservations about the sighting of the takh in Tukhumiin khundi. This latter area has always been considered to lie some distance eastward from the main takh pastures and the local herdsmen had not previously encountered wild horses in this region. However we deeply respect the authority of the well-known entomologist, Dr Z. Kaszab, and therefore include his evidence of having observed the takh there.* We consider A. Yunatov's oral account to A. G. Bannikov (1954, p. 163) of an occurrence near Adji-bogd mountain to be doubtful and even improbable. The explorations organized in the course of the 1947 Transaltai Zoological Expedition (led by A., now Professor, Dashdorj), in which the botanist A. Yunatov and the cartographer D. Badmajav took part, make no mention of sighting wild horses either in their field reports or in the final published results (A. Dashdorj 1949). Kulan were seen in the course of this expedition-sometimes twenty to twenty-five miles away from the route-in herds of up to 10 , sometimes up to 20 . In 1955, following the same route as the previous expedition, we saw only a few herds and these by comparison were of more moderate size.

The seven Przewalski horses seen in the Tukhumiin khundi, GobiAltai aimak, by Dr Kaszab, Director of the Natural History Museum in Budapest, and B. Namhaidorj, scientific assistant of the Biology Institute of the MPR Academy of Sciences, were observed on June 29th 1966. In the middle of that same month the herdsman Tumenulziin Tuvdin of Tonhill somon, Gobi-Altai aimak, had seen eleven on the north slope of the Gobi-Serven chain, and later, in the autumn of the same year, herdsman Hichghee of Altai somon, Kobdo aimak, saw seven quietly grazing in a narrow ravine situated between Takhiin Shar nuruu and Tsahiriin nuruu. An expedition specially mounted by the MPR Academy of Sciences to study the Przewalski horse and sent to the Transaltai gobi in the following two years-1967 and 1968-reported the following evidence: in May and June 1967 they observed fresh tracks of Przewalski horses at the watering places Takhiin us and Todogiin us and, further, saw two of the animals on the northern slopes of the Gobi-Serven chain; in April of the following year they saw one, and in June two, near the Khukh-under and Serven-uul chains.

* See Oryx, December 1966, VIII, 6. 


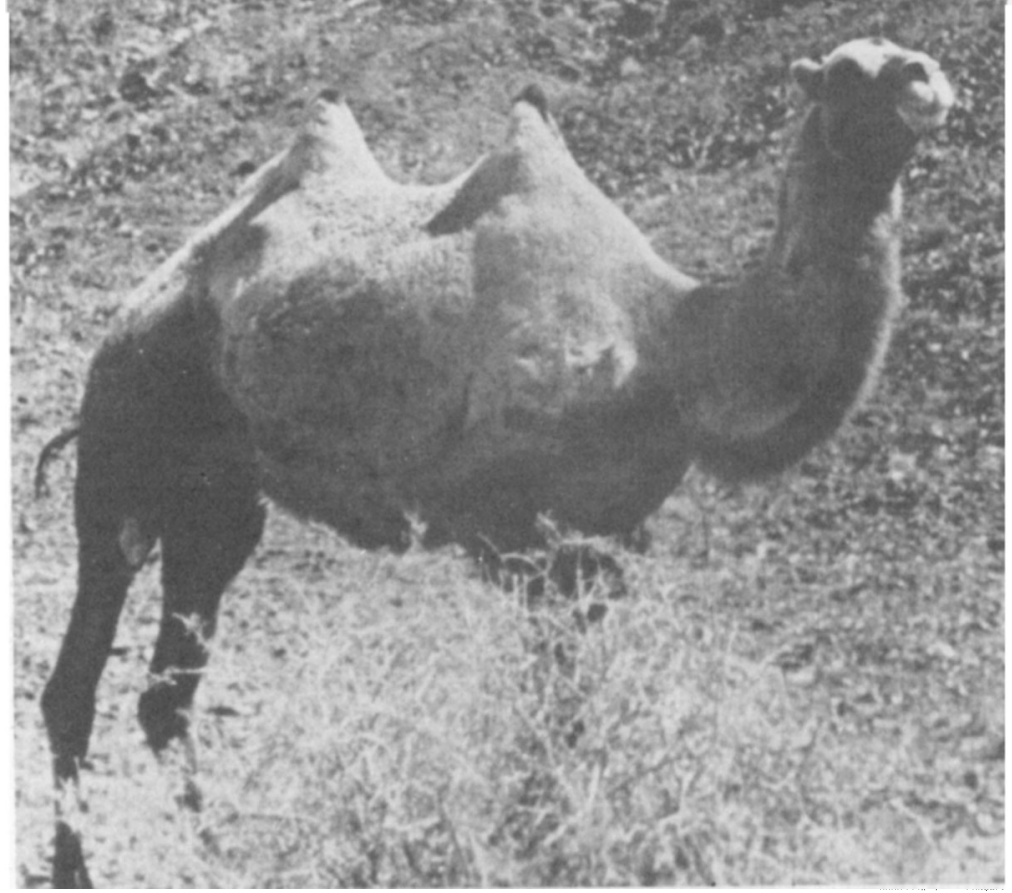

On the basis of this evidence we feel able to say that the Przewalski horse still exists in the wild, but that its numbers are so reduced that any increase must be an extremely slow process. It seems to us that the law forbidding hunting of this species is not enough to save it from extinction. It is necessary on the one hand to organise breeding of the animal in captivity, ${ }^{*}$ in special farms, and at the same time to establish conservation areas where the most numerous Przewalski horses are thought to remain, eliminating competitive grazing by livestock as far as possible.

In the early forties we tried to breed Przewalski horses in captivity in Mongolia, and with this object confined some wild horses at Jargalanta Horse Institute under semi-domesticated conditions, intending not only to breed pure bloods but also to obtain hybrid stock by crossing with Mongolian domestic ponies. We even held races in which domestic ponies and the hybrids competed, the latter winning prizes for being placed in the first five. The local herdsmen of Jargalanta and Orkhon State Farms have several hybrids.

\section{Wild Camel}

The wild two-humped camel, the havtagai, lives in the Central Asian desert. This unique creature has been known since the 13th century.

In the Transaltai we have several hundreds of wild camels, inhabiting several thousand square miles, a much larger area than that of the wild horse, and numbers have increased markedly over the past decade. This shows both that protection is working and,

* The studbook shows that on January 11972 there were 85 stallions and 111 mares in captivity in parks and zoos. 
particularly, that the basic habitat of the animal is beyond the regular range of domestic livestock, the nomadic herdsmen and their animals usually staying outside the wild camel's feeding grounds. It shows, moreover, the toughness of the animal. The havtagai can feed in places far from sources of fresh water.

The result of observations made last year confirms that today the range of the wild camel in the Transaltai gobi is wider than it used to be. N. Dovchin (1968) showed that it is now to be encountered markedly further east than had been previously recorded. Herds can be met with all the year round in the region of the Noyen Bogd hills of South Gobi aimak and the Bayan Gobi deserts of Bayan-Khangor aimak. N. Dovchin $(1967,1968)$ saw wild camels in the neighbourhood of Noyen Bogd, Gurven tes, Shiné-jinst, Nomnigin gobi, Tsagaan Bogd and Tal bulag. In 1962 herdsman Gombo of Shine-jinst somon, Bayan-Khangor aimak, saw a herd of about 80 , including newborn young, near Shargya $Z$ andai us.

Mongolian zoologists maintain, without proof it is true, that the havtagai is the true wild form of the camel, found throughout remembered time in Central Asia within the present limits of the MPR and the Chinese People's Republic. Local inhabitants have often observed the pairing of wild males and domestic females, but, they say, the females separated out by the wild males in this way always return to their own herds. It would appear, therefore, that the wild herds remain 'pure'. Judging from the behaviour, external appearance and a number of morphological features, we incline to the conclusion that the havtagai of today is indeed a primarily wild animal. It is hard to imagine that the 'wild' features sharply distinguishing it from the domestic could possibly have arisen in the descendants of feral animals in so short a time, especially as the conditions in their respective habitats do not differ substantially.

Some authors consider the camel to be a feral form. These conflicting views lead to unnecessary dispute among biologists and historians. Full investigation of the anatomy, biology, distribution, systematics and other aspects of the havtagai have yet to be completed, and we have a considerable task ahead of us. However, A. G. Bannikov has already written a good deal on the anatomy (1945), and there is therefore more for us to do on the other aspects of the question. All the biometric material available on the animal-skins and skulls and two complete specimens-has been collected by expeditions in the present century from places within the present frontiers of the MPR*. The local museum of Gobi-Altai aimak also had, for some time, a wild female with a hybrid calf. This female was taken by local herdsmen when about six weeks old and brought up among local domestic camels. This kind of semidomestication is often practised by gobi herdsmen in Gobi-Altai aimak with both wild camel and kulan.

Descriptions of the habits and distribution of the Mongolian havtagai have been based on the verbal reports of two or three nonzoologist observers and also on the material by specialists listed in - There was a live specimen in the Peking Zoological Gardens in 1963, probably from the small wild population near Lop-nor. Translator's note. 


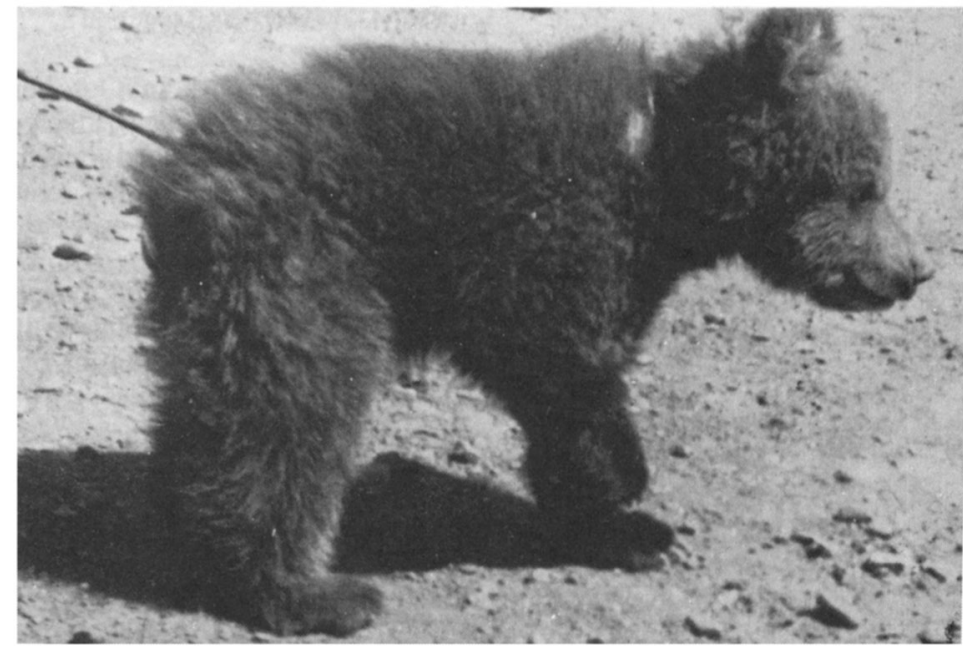

the Bibliography (items numbered 17, 30, 32, 37 and 38). Mammalogists also have available to them the excellent 1945 and 1954 papers of A. G. Bannikov, and additional data may be found in the following specialist works: A. D. Sumikov 1937, 1938; G. P. Dementyev and D. Tsevegmid, A. Dashdorj 1961; O. Shagdarsuren 1959, 1962; A. Bold 1961, 1965; I. Montagu, A. Dashdorj 1965; A. Dashdorj 1966; N. Dovchin 1968.

In spite of what appears to be the camels' satisfactory present status, we are not easy about the conservation of our Central Asian desert. Mongolian zoologists are responsible to the world for safeguarding the havtagai. For the camel's further protection, in addition to the ban on hunting, suitable conditions should be provided for the animals and special breeding farms established.

\section{Gobi Bear}

The Gobi bear, the mazaalai, has long been known to exist in the Transaltai desert. Under the name of 'khungoroos' a bear-like creature appears in the recipe book of Tibetan medicine, and some animal not a brown bear or a monkey or a 'snow-man'-most likely a mazaalai-figures in Mongolian folklore.

The systematics of the mazaalai under the name Ursus pruinosus is doubtful; we have in Ulan Bator only one skin and skull of a grown mazaalai and a live seven-months-old cub*. The mazaalai material collected by A. G. Bannikov is not in the Mongolian University collection.

The mazaalai lives in the region of the mountain massif of Tsagaan bogd, Hatan-Hairhan, Tost and Pemget in the Gobi-Altai mountain system. According to data from recent investigations (O. Shagdarsuren 1962, A. Bold 1967, N. Hotolkhov 1969) the limits of the range of the Gobi bear can be defined as, on the east, Tost and Nemegetu uul, on the west, Aj bogd; the places in this area where the Gobi bear is most often met with are: near Tsagaan bogd

* This cub died following a jaw infection. 
mountain, Tumurtyn khukh, Atas bogd. In October 1966 an MPR Academy of Sciences expedition obtained a fully-grown male Gobi bear, and in April 1969 a local frontier guard caught the newly born cub in the photograph. The diagnostic characters and skull of the male taken in 1966 near Tsagaan bogd were described in 1967 by A. Bold; it is now preserved stuffed in the Ulan Bator State Museum. The range of the mazaalai is thus extremely limited: its numbers are unknown, but the local herdsmen see it quite often and this is how an incautious cub came into the hands of zoologists.

\section{Wild Ass}

The kulan, the wild ass, has extended its range as far east as East Gobi aimak. Wild asses are now quite often to be met with in the Galbyn gobi and Borzorghiin gobi, where none were to be seen twenty years ago; they are also more numerous. Mongolian zoologists (A. Dashdorj 1961, Shagdarsuren 1962, A. Bold 1964, A. Dovchin 1969) have often seen them in herds of from 9 to 49 head, sometimes even hundreds of individuals accompanied by a great number of young. The range of the saiga antelope has also changed substantially in the last twenty years. Formerly it was often met with in the basin of the Great Lakes, especially often near Khirgis nur, near Huislip gobi and Sharghiin gobi.

Besides undertaking administrative measures to conserve our indigenous animals, and considering their extension, we in Mongolia are ready to collaborate with scientific organizations in friendly countries and with IUCN (International Union for Conservation of Nature and Natural Resources). We are also conducting experiments in acclimatisation. The musk-rat Ondatra zibethica appeared during the forties in the Selenga river system; in the fifties it was noticed in the basin of the river Uldz, but has not yet been seen in our reaches of the river Onon. At the end of the sixties we put 50 individuals into the lakes Har-us and Har for acclimatisation. They have settled down well under the new conditions and now, in the seventies, they are already being cropped.

In 1956 and 1957 omul Coregonus altamnalis migratorius were taken from Lake Baikal to Lake Hubsugul. In October 1969 omul were caught in the river Khalkha, where spawn from the Hubsugul omul were incubated, with a body length of $36 \mathrm{~mm}$ at 6 years old. In 1971 and 1972 Baikal omul were caught in Lake Hubsugul aged 7plus and 14-plus years: the body length of the 7-plus females worked out at $370-382 \mathrm{~mm}$, the weight $680-900 \mathrm{~g}$, males $330-395 \mathrm{~mm}$, weight $615-1018 \mathrm{~g}$; body length of 15 year old females $400-460 \mathrm{~mm}$, weight $805-2000 \mathrm{~g}$, males $415-425 \mathrm{~mm}, 805-920 \mathrm{~g}$. We regard the experiment as having been successful and consider that we can already begin economic cultivation of the omul.

At the end of 1960 six beaver Castor fiber were transferred from the Bulgun river and released in the Kobdo, and six beavers from Voronezh Breeding Institute were released in the river Ero. Both these new colonies of beavers have shown that they can survive in their new environments, and releases in these rivers will be repeated.

Deer provide an interesting case. In the East Gobi aimak, 
herdsmen released a pair of red deer Cervus elaphus in the NavckVandan hills to see if they would survive. Now a herd has grown up in completely open steppe. A similar case has occurred with Siberian ibex Capra sibirica in the Gobi-Altai aimak.

To complete the picture we should note that the agricultural cooperative of Haliun somon, Gobi-Altai aimak, at the beginning of 1960 began to breed and keep under semi-domestic conditions more than a dozen head of saiga, and also maintains a number of female wild camels. In the early 1960 s also our zoologists noticed the appearance of the raccoon dog Nyctereutes procyonoides near Lake Buir; it has also been caught near Choibalsan mountain.

Both in respect to protection of nature and the cropping of economic animals we hope to obtain reliable information and help from the zoologists of other socialist countries.

\section{Glossary}

aimak-e.g. province; $d z u d$-hard frozen ground; gobi-semi-desert, wilderness with thin vegetation that can be cropped; Great Hural-parliament; khundi-damp hollow. i.e. dried river bed; nuruu-mountain chain or spine; somon-minor administrative division, e.g. parish (non eccl.); Takhiin Shar-yellow wild horse; uul-village: us-water, i.e. well, spring, pool or small oasis. Translator's note.

\section{Bibliography}

Capital letters indicate language: E-English, G-German, M-Mongolian, $\mathrm{P}$-Polish, R-Russian. *-by inference.

\section{References}

BANNIKOV, A. G. Mammals of the M.P.R. Mlekopitayuschie M.N.R., Moscow, 1954. R

BOLD, A. \& TSEVEGJAV Additional information on the takh. Trudi Inst. Biol. Ac. Sc. M.P.R., No. $11,1963 . \mathrm{M}^{*}$

BOLD, A. Report of the 1964 Transaltai Zoological Expedition, MS Arch. Ac. Sc. M.P.R., n.d. M

BOLD, A. The brown and gobi bears of Mongolia. Tr. Inst. Biol. Ac. Sc. M.P.R. No. $2,1968 . \mathrm{M}^{*}$

DASHDORJ, A. On the occurrence of the beaver in Mongolia. Dokladi Ac. Sc. USSR. Vol. LX, No. 6, pp. 1081-1084, 1948. R

DASHDORJ, A. The rare animals of Mongolia, Journ. Shinjlekh Ukhaan (Science), No. 2, Ulan Bator, 1949. M

DASHDORJ, A. On the fauna of Mongolia and the question of hunting. Tr. Mong. State Univ., No. 3(23), 1966. M

DASHDORJ, A., TSENDSUREN, A. \& DULMAA, A. A Short Guide to the Freshwater Fauna of Mongolia, Ulan Bator, 1970. M

DEMENTYEV, G. P. Mammals of the Transaltai Desert (Mlekopitayuschiye Zaaltaiskoi Pustyni), Moscow Univ., 1961. R

DEMENTYEV, G. P. \& TSEVEGMID, D. The wild camel in Mongolia (Dikii verblyud v Mongolii), Priroda (Nature) No. 1, Moscow, 1963. R

DEMENTYEV, G. P., SHAGDARSUREN, O. \& BOLD, A. A zoogeographical survey of the Mongolian desert. Tr. Mong. State Univ., Vol. 9, Pt. 2, 1966. R

DOVCHIN, N. On the distribution of the takh. Journ. Ac. Sc. M.P.R. (Science), No. $1,1960 . \mathrm{M}$

DOVCHIN, N. The past, present and future of the rare animals of Mongolia. Journ. Ac. Sc. M.P.R. (Science and Life), No. 3, 1968. M

DOVCHIN, N. A short account of the study of the Przewalski horse. Tr. Inst. Biol. Ac. Sc. M.P.R., No. 4, 1969. M

DULAMTSEREN, S. Discovery of the tamarisk gerbil in Mongolia. Izv. Ac. Sc. M.P.R., No. 4, 1969. M 
DULAMTSEREN, S. Guide to the Mammals of Mongolia, Ulan Bator, 1970. M

EREGDEN-DAGVA, D. The rare animals of Western Mongolia. Priroda (Nature) No. 4, Moscow, 1954. R

HAVESON (Gaveson), Y.I. Craniological differences between wild and domestic camels. Dok. Ac. Sc. USSR, Vol. LX, No. 6, p. 1093, 1948. R

HAVESON (Gaveson), Y. I. Morphological data supporting the theory that horses of the Mongolian group are descended from the Przewalski horse, Moskovskoe Obshchestvo Ispytatelei i Prirody, Bull. Biol. Sect, Nov. Ser., Vol. 63, Pt. 4.pp. 119-121, 1958. R

HEPTNER (Geptner), V. G., NASIMOVITCH, A. A. \& BANNIKOV, A. G. Mammals of the Soviet Union (Mlekopitayushchiye Sov.Soy.), Vol. I, Moscow, 1961. R

KASZAB; Z. New sighting of the Przewalski horse, 'Oryx', Vol. VIII, No. 6, London, 1966. E

KHOTOLKHU, N. and others. Mammals of the Transaltai Deserts, Trans. Inst. Biol. Ac. Sc. M.P.R. No. 6, 1972. 59-83. M

KOWALSKI, K. New data on the distribution of mammals in Mongolia, Acta Zool. Cracoviensa, Vol. 13, No. 1, n.d. E? P?*

KUZNETSOV, B. A. Hunting Economy of Mongolia, Okhota $i$ Okhotnichye Khozaistvo, No. 7, pp. 42-43, Moscow, (?), 1965. R

Law on hunting (Zakon ob Okhotye), Zhurn. Khozyaistvo, No. 4 (22), Ulan Bator, 1930. R

MONTAGU, I. The wild horse, Animals, Vol. IV, No. 16, London, 1964.E

MONTAGU, I. Communication on the current survival in Mongolia of the wild horse ( $E$. przewalski), wild camel (C. bactrianus ferus) and wild ass (E. hemionus), P.Z.S.Lond., Vol. 144, Pt. 3, pp. 425-429, 1965. E

PIECHOCKI, R. \& PETERS, Y. Allgemeine Zoologischer Reisebericht ueber die Mongolisch-Deutschen Biologischen Expeditionen 1962-1964. Mitt. Zool. Mus. Berlin, Vol. XLII, pp. 3-42, n.d. G

PIECHOCKI, R. Der südasiatische Biber (C. fiber birulai Serebrennikov), Arch. Naturschuetz und Landschaftsforsch., No. 7, pp. 31-46, 1967. G

PIECHOCKI, R. Beitrag zur Avifauna der Mongolei, Mitt. Zool. Mus. Berlin, Vol. XLIV, No. 2, 1968. G

SHAGDARSUREN, O. \& BOLD, A. Report of the Transaltai Zoological Expedition, Inst. Biol. Ac. Sc. M.P.R., 1961. M

SHAGDARSUREN, $O$. Information on the Mammals of the Transaltai gobi. Izv. Ac.Sc.M.P.R., No. 1, 1962. M

SHAGDARSUREN, O. Rare Mammals of the M.P.R. Ulan Bator, 1962. M

SIMUKOV, A. D. Through the desert of the Western Gobi, Sovremenniya Mongolia (Contemporary Mongolia) No. 6, p. 25 (1937) and No. 1, p. 26 (1938), Ulan Bator, 1937-8. R \& E?

STUBBE, M. \& CHOTOLCHU, N. Zur Säugetier Fauna der Mongolei. Mit.Zool. Mus.Berlin, Vol. XLIV, No. 1, 1968. G

TSEVEGMID, D. \& DASHDORJ, A. Report of the 1955 Transaltai Zoological Expedition, MS Arch., Inst. Biol. Ac.Sc. M.P.R., n.d. M

TSEVEGMID, D. On the question of conserving the Przewalski horse-the takh, Journ. Science, No. 4, pp. 35-38, Ulan Bator, 1958. M

TSEVEGMID, D. Protect the rarest animals in the world, Priroda (Nature), No. 5, Moscow, 1959. R

TSEVEGMID, D. \& DEMENTYEV, G. P. On the wild camel in the M.P.R., Uchenye Zapiski, Mong. State Univ., Vol. IX, No. 2 (18). 1966. R

\section{Wild Ass Census in USSR}

Outside Mongolia the Asian wild ass, once widespread between the Syrian and Mongolian deserts, now survives only in a few widely scattered places. In the USSR it occurs only in two reserves in Turkmenistan, Badkhyz and Barsa Kelmes, lying between the Murgab and Tedzhen rivers. Here the kulans or dziggetai, as they are called, have recently been censused, and found to have increased from an original low point of a few dozen to 800 . 